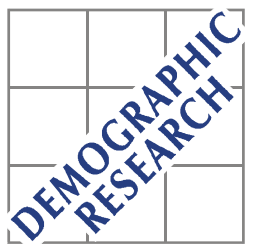

Demographic Research a free, expedited, online journal of peer-reviewed research and commentary in the population sciences published by the Max Planck Institute for Demographic Research Doberaner Strasse 114 D D-18057 Rostock · GERMANY www.demographic-research.org

DEMOGRAPHIC RESEARCH

VOLUME 7, ARTICLE 10, PAGES 389-406

PUBLISHED 27 AUGUST 2002

www.demographic-research.org/Volumes/Vol7/10/

DOI: $10.4054 /$ DemRes.2002.7.10

Descriptive Findings

\title{
How premarital children and childbearing in current marriage influence divorce of Swedish women in their first marriages
}

Guiping Liu

(C) 2002 Max-Planck-Gesellschaft. 


\section{Table of Contents}

1 Introduction 390

2 Data and method 391

2.1 Data 391

2.2 Method 396

3 Findings 397

4 Conclusion 404

5 Acknowledgments 404

$\begin{array}{ll}\text { References } & 405\end{array}$ 


\title{
How premarital children and childbearing in current marriage influence divorce of Swedish women in their first marriages
}

\author{
Guiping Liu ${ }^{1}$
}

\begin{abstract}
By using a Swedish register data set and applying hazard models with unobserved heterogeneity, this study demonstrates that the partners' childbearing history plays an important role in predicting the divorce risks of families with various combination of premarital children. Families with premarital children definitely have a higher risk of divorce than do those without premarital children. Producing a common child reduces the divorce risk, but as the youngest common child gets older, his or her role in maintaining family bond weakens. Families which the wife has premarital children by another man decidedly have a higher risk of divorce than do families with other combinations of premarital children. Other findings deviate from what has been reported in the literature.
\end{abstract}

Max-Planck-Institute for Demographic Research, Doberaner Strasse 114, Rostock, Germany. Phone: +49 3812081 189, Fax: +49 3812081 489, email: liu@demogr.mpg.de 


\section{Introduction}

The existence of premarital children may complicate family relationships. They also make the study of marital instability more complicated. No wonder, therefore, that the literature on the effects of premarital childbearing is contradictory. In applying the concept of 'marriage-specific capital' to explain family instability in second and later marriages, Becker, Landes and Michael (1977) maintained that 'children (and perhaps other specific capital) from previous marriages could reduce the stability of the current marriage because they are a source of friction'. White and Booth (1985) claimed that the presence of stepchildren is a destabilizing influence in late remarriages and a major contributor to their somewhat greater rate of divorce. Similarly, Furstenberg (1990) concluded that because of the ambiguity of family norms and because bonds between stepparents and their children are weaker and sometimes fraught with conflict, relationships in stepfamilies generally are less harmonious and gratifying. Both Cherlin and Furstenberg have paid much attention to the high instability of American stepfamilies since the late 1970s. Cherlin (1978) used the term incompletely institutionalized family' in his explanation of the high rates of separation and divorce in remarried families in the United States. In 1979 and 1984, Furstenberg described this as 'distinctively different family form', which he called 'the new extended family' in 1987 (For an overview, see Cherlin \& Furstenberg, 1994).

It is often assumed that having common children can improve a remarried couple's relationship with each other because common children provide closer ties between the parents. In contrast, Ganong and Coleman (1988) suggest that having common children does not really cement bonds within families; but they only focus on the changing ties among family members and do not deal directly with divorce risks in families.

Using the National Longitudinal Survey of Youth (NLSY) and applying a joint modeling procedure, Upchurch, Lillard and Panis (2001) found no direct effect of nonmarital children on the risk of union dissolution. They claimed that 'non-marital children appear to delay women's marriage formation, but once married, the non-marital children do not contribute to the risk of separating'. They drew their conclusions after accounting for the 'endogeneity' of the multiple processes.

Some research based on Swedish data shows that women who have premarital children have an excess risk of divorce in their first marriage (Hoem, 1995; Hong, 1996; Andersson, 1997; Liu, 2002a). Yet these researches do not show how different types of premarital births influence the divorce risk of families differentially, because no suitable data was available at that time. Others tried to figure out why mothers with premarital children have a higher risk of divorce. They have hypothesized that the remaining excess risk of divorce for mothers of premarital children may stem from the fact that their husband are not these children's biological fathers' (Qvist et al. 1995; for a 
review, see Andersson, 1997). Actually, using Norwegian registers, Kravdal (1988) has found that for women in their first marriages, the presence of premarital children indeed lead subsequently to higher risk of divorce, even the father of the premarital children is the woman's current husband.

With a newly structured register data set from Statistics Sweden, this study focuses on two issues: First, how do various compositions of a set of children born before the current marriage formation influence family stability? Second, does the presence of common children reduce the divorce risks? We focus only on the empirical evidence, and leave further theoretical explanations for another time.

We limit our investigation to the first marriages of Swedish women. The reasons are as follow. First, it facilities our study, in light of the complication of the issues. Second, the previous Swedish (and Norwegian) studies mentioned above dealt with first marriages of women, too. We intend to make our results comparable somehow. Third, entering marriages is rather selective for Swedish women and entering higher marriages is more highly selective. We prefer to treat separately for higher orders of marriages in other investigations.

\section{Data \& Method}

\subsection{Data}

For our hazard analysis of the divorce risks of Swedish women in their first marriages, we use a unique set of Swedish individual-level register data with ample information on demographic profiles and on social and economic characteristics. The data set contains records for both men and women. It covers the period from 1945 through 1999. We include eight covariates in our models, namely, (1) composition of any set of premarital children by parenthood, (2) woman's age at first marriage, (3) marital ordinal of her husband, (4) total number of children of both partners, (5) an indicator of pregnancy at marriage formation, (6) an indicator of whether the woman is pregnant in the current marriage, (7) an indicator that a child has been born in the current marriage, and (8) age of the youngest common child. The woman's age at first marriage, the indicator of a pregnancy in the current marriage, marital ordinal of her husband and the age of any youngest common child are straightforward and are readily obtained from the raw data set. Total number of children of both partners (include all children with various parenthood) can easily be obtained from the data set, too.

The rest of the covariates need some explanation and we now describe how we got them from the raw data set. 
The Swedish register database contains a separate record for each individual. The record contains the individual's ID number and date of birth as basic information, and has other related information in addition (educational attainment, annual income, employment status, information on marriage and divorce, childbearing history, and so on). A woman's record contains the birth dates of all her children, their ID numbers, and the ID number of her husband and the ID number of her any partner who produced children with her before the current marriage formation. In a man's record, we have the same information except the information about his children. Children are related to men via women's records. In a child's record, we have its date of birth, the biological mother's ID number, and the biological father's ID number. By comparing the ID numbers of a child's biological father with the ID number of the mother's husband, we obtain complete information about motherhood and fatherhood. This is to say that we know whether any child is a stepchild to any of the parents in the family and whether he/she is a biological child to any of the parents or to both parents together. We also know whether any child was born before the current marriage (premarital children) because we know the date of marriage. In Sweden, it is not unusual that a woman already has children when she enters first marriage. A premarital child could have a father other than the mother's current husband, or it could be a common child produced by the current couple before marriage formation. In both cases we know the children's parenthood situation. A woman in first marriage could also have stepchildren from her husband's relations with other woman either in form of cohabitation or through judicial marriages before the current marriage formation.

We define a fixed covariate called 'the type of premarital children' according to the different possibilities of parenthood. A description of the types of premarital children is summarized in Table 1. It is an inherent weakness of our data that we have no information on non-marital cohabitation or on where the children live. In most cases, a woman's children live with her. If her current husband has children with other women, those children usually live with their biological mothers. We cannot account for children's residence in our analysis, only for their parenthood. 
Demographic Research - Volume 7, Article 10

Table 1: $\quad$ Types of premarital children in the current marriage

\begin{tabular}{lr}
\hline \multicolumn{1}{c}{ Descriptions } & Symbols \\
\hline All premarital children are the husband's with other women & m-type \\
All premarital children are the wife's with other men & w-m-mixture \\
There are some premarital children of each of the above kinds & c-type \\
All premarital children are common to the wife and husband & c-m-mixture \\
$\begin{array}{l}\text { Some of the premarital children are common to the wife and husband, } \\
\text { other are the husband's with other women }\end{array}$ & c-w-mixture \\
Some of the premarital children are common to the wife and husband, \\
Premarital children are both c-type, w-type, and m-type
\end{tabular}

We have also constructed a couple of related variables. We use the number of common children born in the current marriage as a time-varying variable. In addition, we include the separate numbers of the various types of premarital children as time-invariant covariates. On this basis, we have introduced a binary indicator of childbearing in the current marriage as another time-varying covariate.

We have also constructed another time-invariant covariate, namely, a binary indicator of known pregnancy at marriage formation, based on some reasonable judgments. Given the birthday of a child in the current marriage, we have estimated the beginning of a known pregnancy by counting seven months backward from the date of the child's birth. (We assume that a woman becomes certain of her pregnancy about two months after conception). If the date of a woman's known pregnancy is earlier than the date of her marriage, we assume that the woman knew she was pregnant at marriage. Since we have the ID number of the child's biological father, we also know whether the mother's husband is the child's biological father. Therefore, we know whether the mother was pregnant with a stepchild to her husband when she married him. This mainly lets us see to what degree her husband, before marriage, tolerated her pregnancy by another man, and we can study its effect on the subsequent marital dissolution risks. 
A simplified childbearing history of the couple is indicated in the last panel of Table 3. The coefficients result from a model with four-way interaction between (1) the type of premarital children, (2) the indicator that a woman is currently pregnant, (3) the age of any youngest common child, and (4) an indicator of common childbearing in the current marriage. The immense Swedish registers allow us to make such a luxurious segmentation of data, and it leads to some interesting and unusual findings.

The time variable of our hazard analysis is the duration of the first marriage. We include 'only' women who got married between January of 1980 and December of 1998. We follow the general assertion that the timing of marriages only plays important role in predicting marital dissolution within 15 years of marriages, observations are censored at 15 years of marriage. Observations are also censored at the emigration of the man or the woman, at the death of the spouse, and at the end of 1998 (by doing so, some marriages observed were exposed to divorce risk for very short time, but we assume that the impact is minor). Table 2 shows the simple statistics of variables in the model. For time-varying variables, we do not give the number of woman in different status, instead, we only calculate the total number of divorces, total exposures and total occurrences in woman years. In this study, we have only included women born in Sweden to eliminate the cultural influence of women's divorce behavior. 
Table 2: $\quad$ Simple statistics of the variables

\begin{tabular}{|c|c|c|c|c|c|}
\hline Variable & Level & $\begin{array}{l}\text { No. of women } \\
\text { in exposures }\end{array}$ & No. of divorces & $\begin{array}{r}\text { Total Exposures } \\
\text { (woman years) }\end{array}$ & $\begin{array}{r}\text { Total Occurrences } \\
\text { (women years) }\end{array}$ \\
\hline Total & & 509093 & 80964 & 4203373.37 & 41969.98 \\
\hline \multirow[t]{7}{*}{ Age at marriage of woman (year) } & (below 16 ) & 3 & 1 & 36.72 & 0.95 \\
\hline & $16-19$ & 11146 & 4336 & 89444.27 & 2191.00 \\
\hline & $20-23$ & 96491 & 23529 & 863785.60 & 12228.69 \\
\hline & $24-28$ & 210861 & 31829 & 1784154.92 & 16517.38 \\
\hline & 29-35 & 149035 & 17581 & 1178023.85 & 9115.72 \\
\hline & $36-49$ & 41265 & 3686 & 287551.69 & 1915.82 \\
\hline & $(50+)$ & 292 & 2 & 376.31 & 0.4219 \\
\hline \multirow[t]{3}{*}{ Marital ordinal of her husband } & first & 474212 & 73512 & 3944073.31 & 38104.62 \\
\hline & second & 33084 & 6919 & 248820.83 & 3591.57 \\
\hline & third or higher & 1797 & 533 & 10479.23 & 273.80 \\
\hline \multirow[t]{4}{*}{$\begin{array}{l}\text { Indicator of woman's pregnancy } \\
\text { at marriage formation }\end{array}$} & $\begin{array}{l}\text { not pregnant at } \\
\text { marriage formation }\end{array}$ & 443285 & 68989 & 3593325.23 & 35715.90 \\
\hline & $\begin{array}{l}\text { pregnant with child of } \\
\text { the current union }\end{array}$ & 65744 & 11944 & 609676.30 & 6235.01 \\
\hline & $\begin{array}{l}\text { pregnant with } \\
\text { stepchild to the } \\
\text { husband }\end{array}$ & 63 & 31 & 370.27 & 19.07 \\
\hline & $\begin{array}{l}\text { (pregnant status } \\
\text { unknown ) }\end{array}$ & 1 & 0 & 1.57 & 0.00 \\
\hline \multirow[t]{5}{*}{ Total number of couple's children } & childless & - & 13465 & 550499.66 & 6796.38 \\
\hline & 1 & - & 15314 & 842623.66 & 7984.22 \\
\hline & 2 & - & 30620 & 1771503.17 & 15954.86 \\
\hline & 3 & - & 13987 & 759820.35 & 7273.21 \\
\hline & $4+$ & - & 7578 & 278926.54 & 3961.35 \\
\hline \multirow{2}{*}{$\begin{array}{l}\text { Indicator of common child born in } \\
\text { the current marriage }\end{array}$} & yes & - & 42031 & 2484315.25 & 21938.17 \\
\hline & no & - & 38933 & 1719058.12 & 20031.81 \\
\hline \multirow[t]{7}{*}{ Age of youngest common child } & no common child & - & 19431 & 587486.89 & 9876.75 \\
\hline & woman pregnant & - & 402 & 311367.44 & 115.37 \\
\hline & age below 1year & - & 1088 & 310882.99 & 423.72 \\
\hline & $1-2$ years & - & 14329 & 1018407.52 & 7477.59 \\
\hline & $3-5$ years & - & 24873 & 917856.11 & 13156.12 \\
\hline & $6-8$ years & - & 11898 & 530045.64 & 6197.25 \\
\hline & 9 years and above & - & 8943 & 527326.78 & 4723.20 \\
\hline \multirow[t]{8}{*}{ Types of premarital children } & no premarital children & 222945 & 31100 & 1876437.29 & 16019.90 \\
\hline & m-type & 22302 & 5132 & 167734.83 & 2614.50 \\
\hline & w-type & 14514 & 4410 & 107122.06 & 2263.47 \\
\hline & w-m-mixture & 8853 & 2794 & 53104.18 & 1453.84 \\
\hline & c-type & 202485 & 29293 & 1706375.72 & 15336.27 \\
\hline & c-m-mixture & 18005 & 3526 & 141103.94 & 1829.49 \\
\hline & c-w-mixture & 15802 & 3575 & 122218.16 & 1867.79 \\
\hline & $c-w-m-m i x t u r e$ & 4187 & 1134 & 29277.19 & 584.72 \\
\hline
\end{tabular}




\subsection{Method}

We used the following intensity regression model, to determine the risk of divorce in the first marriage:

$$
\begin{aligned}
\ln \mu_{i}(t)=y(t)+\alpha_{1} \text { MarAge }+\alpha_{2} \text { Parity }+\alpha_{3} \text { Mmord }+\alpha_{4} \text { PregMarl } \\
+\boldsymbol{\alpha}_{5} \text { PreKidType } * \text { NewKids } * \text { PregMar } 2 * \text { YChildAge }+v_{i} ;
\end{aligned}
$$

where $t$ is the duration since marriage formation;

$\mu_{i}(t)$ is the intensity of divorce at duration $t$ for individual $i$;

$y(t)$ is the baseline log-hazard;

$\alpha_{j}, j=1,2,3,4$, are parameters to be estimated;

$\boldsymbol{\alpha}_{5}$ is a vector of parameters to be estimated;

MarAge is the age at first marriage of the woman (fixed variable);

Parity is the couple's total number of children with various parenthood(time-varying variable);

Mmord is the marital ordinal of the husband(fixed variable);

PregMarl is an indicator of pregnancy at marriage (fixed variable);

PreKidType is a vector of indicators of types of premarital children (fixed variable);

NewKids is an indicator that the spouses have common children

in the current marriage (time-varying variable);

PregMar2 is an indicator that the woman is pregnant

in the current marriage (time-varying variable);

YChildAge is the age of any youngest common child of the couple (time-varying variable);

$v_{i}$ captures woman-specific unobserved heterogeneity,

a normal distribution with zero mean and variance of Sigma square.

Age at marriage is categorized into five groups, namely, 16-19, 20-23, 24-28, 29-35, and 36-49 years. We have excluded women married at age below 16 or older than 49 from calculations. Age group 24-28 is the omitted reference group. Age of the youngest common child is categorized into 5 groups, namely, below 1 year, 1-2 years, 3-5 years, 6-8 years, and 9 years or older. We have used grouped versions of our continuous variables because it facilitates interpretation. We specify a residual component in the model to capture any unobserved heterogeneity. It is arbitrarily defined as a normal 
distribution with zero mean and Sigma square variance. Since the observation unit in the data set is a woman, therefore, the unobserved-heterogeneity component in the model captures woman-specific heterogeneity, as we noted above. In practice, we run first a model without unobserved heterogeneity component, we run second a model with such a term. We did not find any estimates reversed in direction. However, the likelihood ratio test shows that the second model improves significantly the model fit. We also find that after capturing woman's specific heterogeneity, the differences among the estimates became highly distinct. As following, we will present the results obtained from running the model with unobserved heterogeneity component.

\section{Findings}

We first describe Table 3. The woman's age at first marriage is 'only' a control variable and, as usual, the divorce risk declines as this age increases. We also regard parity (of the couple) as a control variable. We find that, couple who remained childless or who produced only one child can be classified as one group according to the level of divorce risks. Couple who has produced two or more children can be classified as another group. The basic trend is that the divorce risk decreases as the number of children increases. The presence of the second child reduces half of the relative risk of divorce. Women who get married with a man in second marriage do not have substantially high risks of divorce, whereas, woman who marry a man in third or higher order of marriage have much higher divorce risk, compared with women who marry a man in first marriage.

As expected, women who were pregnant with a baby of the current union at the time of marriage formation had a much lower risk of divorce than that of women about to give a birth to a stepchild to her husband. Women who were not pregnant at marriage had the lowest risk of divorce. Pregnancy at marriage raised the risks of divorce regardless of the parenthood of the coming child.

We turn now to the covariates of greatest interest to us; they are in the last panel of Table 3. 
Table 3: $\quad$ Relative risks of divorce of Swedish women in first marriages




As we have noted, the lower panel of Table 3 is the result of an interaction among four covariates. One sees that the panel consists of two sets of columns, namely, (1) a single column for families with no common child born in the current marriage, and (2) a set for families with common children born in the current marriage. In the latter set, one finds the relative risks of divorce for pregnant women and for women with a youngest common child at various ages.

From the first column of the lower panel of Table 3 one finds that families with premarital children of c-type have slight lower risk of divorce. All other families show higher risks of divorce than that of childless families before the current marriage formation. This is to say, for families without childbearing after the current marriage formation, those with stepchildren to either partner have substantially higher risks of divorce than childless families do.

In the set for families with common children born in the current marriage, the relative risk displayed on the top of each column is always the smallest, except in the first column, where the second figure is the smallest. This finding implies that the existence of premarital children before the current marriage raises the subsequent divorce risk of the families where the woman is in her first marriage. Families where the couple produces a common child before the current marriage also have higher risk of divorce than that of families where there is no any premarital child. We can conclude that for families with childbearing in the current marriage, the presence of premarital children indeed lead to an excess risk of divorce independent of the parenthood of these children.

By explaining the results shown on Table 3 and Figures 1a and 1b, we describe how various compositions of a set of children born before the current marriage formation influence divorce of woman's first marriage.

Table 3 suggests that families in which the wife had premarital children have particularly high risks of divorce. We see this from three comparisons. First, families with w-type premarital children have a higher risk of divorce than do those with m-type premarital children. Second, families with a c-w-mixture of premarital children have a much higher risk of divorce than do those with c-m-mixture premarital children. Third, families with a w-m-mixture of premarital children have a much higher risk of divorce than do those with a c-m-mixture of premarital children. This finding is so robust that it holds not only for families that do or do not have a common child in the current marriage but also for families where the wife was pregnant with the spouses' common child at marriage. It also holds true regardless of the age of the youngest common child.

Remember that premarital children of w-type are produced in the mother's relation with another man than her current husband. The children usually live with their mother and may have a harder time getting along with their stepfather and their half-siblings. As a result, they may cause much friction in the family. Another reason may be that 
men are much less tolerant of their stepchildren than women are. Men may be more concerned about their own children. The families with premarital children of a w-mmixture and where the couple had not produced common child after they got married had the highest risk of divorce.

Figure 1a, based on Table 3, gives us a clearer understanding of the findings. The stippled blue line stands for the relative divorce risks of families with no premarital children. It is located in the lowest part of the field, showing the lowest relative risks of divorce. The curve for families with premarital children of c-type is just above the one for those families with no premarital children. This important point confirms that having children common to the current union before marriage formation could cause a higher risk of subsequent divorce than having no premarital children and having these children within marriage. The next is the curve for families with premarital children of $\mathrm{m}$-type, and the curve further above is one for families with premarital children of c-mmixture. The four curves move up smoothly one above another. The curves for families with premarital children of w-type, c-w-mixture, w-m-mixture, and c-w-m-mixture, are much higher up, which implies substantially higher risks of divorce for these families. After the youngest common child turned three years old, families with premarital children of a c-w-m-mixture had a higher risk of divorce even than families with premarital children of a w-m-mixture. Most of the curves show a decreasing risk of divorce as the age of the youngest common child got beyond 3 years of age, but the trends are not consistent. For instance, divorce risk decreases only after age 6-8 for the groups 'no-premarital children' and c-w-mixture', and the risk increases at age 9 or older for the groups 'c-w-m-mixture' and 'w-m-mixture'. 
Figure 1a: Divorce risks according to the age of the youngest common child, separately according to parenthood of any premarital children.




Figure 1b: Divorce risks according to the type of premarital children, separately according to age of the youngest common child.

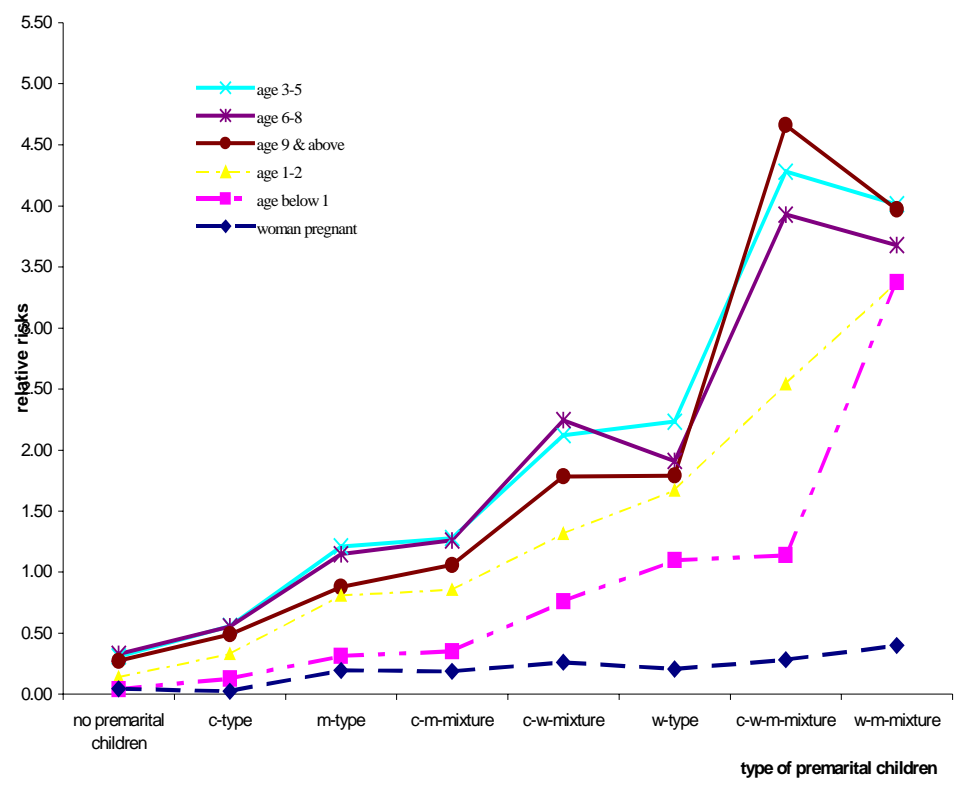

Figure $1 \mathrm{~b}$ displays the same table panel from a different angle. It confirms further what we have pointed out above. First, a woman's pregnancy with a common child clearly reduces the risk of marriage dissolution no matter what kind of premarital children the spouses had before current marriage formation. Second, when the youngest common child was 3 years or older, the age of the youngest child no longer influenced the pattern of divorce risk; the type of premarital children then became the dominant factor shaping the curves that represent the relative risk. Third, families with common children aged 3-8 years old had the highest risk of divorce, and when the youngest common child reached 9 years or older, the divorce risk tended to decrease. But for families with premarital children of a c-w-m-mixture, the relative divorce risk reached a peak after the youngest common child reached 9 years or older. A possible reason may be that in such families, the older the children are, the more likely is friction to occur. Fourth, the age of the youngest child barely had an impact on the divorce risk for families with premarital children of w-m-mixture--in Figure $1 \mathrm{~b}$, the points representing the relative 
risks of such families come close together. Fifth, Figure $1 \mathrm{~b}$ also confirms that families in which the wife had premarital children who were not her husband's have particularly high risks of divorce. The curves go up from the left to the right part of the diagram field where the relative risks for families with premarital children of c-w-mixture, wtype, $\mathrm{c}-\mathrm{w}-\mathrm{m}$-mixture and $\mathrm{w}-\mathrm{m}$-mixture are displayed.

We also note that producing common children after the current marriage was formed lowered the risk of divorce for all types of families. Relative risks in Table 3 show that families where the couple did not produce common children in the current marriage had very high risks of divorce. But as the youngest common child grew, say, to age three, the families with premarital children of c-w-m-mixture experienced a higher risk of divorce. This could stem from the fact that as children grow up, tension tends to grow within the family. However, producing common could not be the cause of lowering divorce risk, instead, it could be the fact that the couple has an optimistic expectation toward their marriage and they produced subsequently a child after the marriage formation. It is equally true that the presence of a common child could serve as a tie of the family relation or somehow as an obstacle of divorce. Having common children before marriage formation cements bonds in the family. This conclusion is supported by the following facts. Families with premarital children of the c-type had the lowest risk of divorce of all families. Families with premarital children of a c-mmixture had a lower risk of divorce than families with premarital children of the $\mathrm{m}$ type, and families with premarital children of a c-w-mixture had a lower risk of divorce than those families with premarital children of the w-type.

In our discussion above, we have not really accounted for the fact that there is an overlap in the lower parts of Table 3 between total number of couple's children and the type of the premarital children. For instance, if a family had premarital children of a c$\mathrm{w}-\mathrm{m}$-mixture and the couple produced a new child in the marriage, the total number of children would be at least 4 in the family. Therefore, figures in the lower panel of Table 3 are for women of different parities. Ideally, we should make an interaction between couples' parity and the four covariates in the lowermost of panel, but this would cause another problem--we would lose a complete combinations of premarital children with various parenthood as shown on Table 1 and Table 3. The reason is that the families with low parity, say, one or two do not have various type of premarital children (see, Liu, 2002b).

However, ignoring the interaction has not harmed the essence of our findings. We see this as follows. First, we have seen in Table 3 that divorce risks decrease when the couple's parity increases. Families where the couple had two or more children had a much lower divorce risk than families where the couple only had one child or had not yet a child. Second, the figures in the lower panel of Table 3 show that families with premarital children of the $\mathrm{c}-\mathrm{w}-\mathrm{m}$-mixture have a much higher divorce risk than do the 
families with premarital children of the c-type, m-type and w-type. The minimum number of children of the former families is 3 , but the latter types of families could have only one child. This suggests that the divorce patterns shown in Table 3 are determined mainly by the parenthood of the premarital children and the effect of premarital children seems to overwhelmingly overshadow the effect of the couple's parity.

\section{Conclusion}

Families with premarital children had higher risks of divorce than families without premarital children. Having common children is always an indicator for lower divorce risks. Though, the reversed causality may exist. Premarital children from a woman's relationship with another man made the marriage highly unstable. Premarital children to the man were much less important than premarital children to the woman. This depends probably on the fact that the women's premarital children usually live with their mothers in the current couple's household, whereas, men's premarital children usually do not. The age of the youngest common child plays an additional though minor role in predicting family stability. Our findings concerning the effect of premarital children and the pattern of divorce risks in first marriages hold true even after the total number of children of the couple is controlled.

Our investigation also finds limitation of new Swedish registers. We do not know with whom the premarital children are living. We do not have information about premarital cohabitation, therefore, we can only deal with judicial marriage and do not concern union orders of both premarital cohabitation and marriages. Selection of the partner into marriages is also a disadvantage of the data we apply.

\section{Acknowledgements}

I thank Statistics Sweden for providing the data for this study. I am particularly grateful to Jan Hoem for his extensive substantive and editorial comments and his support throughout the whole process of this investigation. Thanks go to Jonathan MacGill, who did the programming to convert the raw data into the format needed for the aML software. I received helpful comments from Gunnar Andersson on an earlier draft of this paper. I would like to thank Elizabeth Zach and Susann Backer for their language editing services. Finally, three anonymous reviewers of Demographic Research are greatly acknowledged. 


\section{References}

Andersson, G. (1997). "The Impact of Children on Divorce Risks of Swedish Women". European Journal of Population 13/2: 109-145.

Becker, G.S., Landes, E. M., Michael, R. T. (1977). "An Economic Analysis of Marital Instability". The Journal of Political Economy 86/6: 1141-1188.

Cherlin, A. (1978). "Remarriage as an Incomplete Institution". American Journal of Sociology 84/3: 634-650.

Cherlin, A. J., Furstenberg, Jr., F.F. (1994). "Stepfamilies in the United States: a reconsideration". Annual Review of Sociology 20: 359-381.

Furstenberg Jr., F. F. (1990). "Divorce and the American Family". Annual Review of Sociology 16: 379-403.

Ganong L. H. and Coleman M. (1988). "Do Mutual Children Cement Bonds in Stepfamilies?". Journal of Marriage and the Family 50: 687-699.

Hoem, J. M. (1995). "Educational Capital and Divorce Risk in Sweden in the 1970s and 1980s". Stockholm Research Reports in Demography No. 95. Stockholm University, Demography Unit.

Hong, Y. (1996). "Patterns of Divorce Risk in the 1970s and 1980s for Swedish Women with a Gymnasium Education". Stockholm Research Reports in Demography No. 103. Stockholm University, Demography Unit.

Kravdal, Ø., 1988. "The Impact of First-Birth Timing on Divorce: new evidence from a longitudinal analysis based on the Central Population Register of Norway". European Journal of Population 4: 247-269.

Liu, G. (2002a). "Divorce Risk of Swedish Women in Their First Marriages - two cohorts born in 1950 and 1960". Rostock, MPIDR Working Paper WP-2002-012. http://www.demogr.mpg.de/papers/working/wp-2002-012.pdf

Liu, G. (2002b). "How Premarital Children and Childbearing in the Current Marriage Influence Family Stability--descriptive findings based on Swedish register data". Rostock, MPIDR Working Paper WP-2002-16. http://www.demogr.mpg.de/ papers/working/wp-2002-016.pdf

Qvist, J., Uhlen, M., and Sjoeberg, I. (1995). Skilsmaessor och separationer: bakgrund och utveckling. Statistics Sweden, Stockholm: Demografiska Rapporter 1995: 1. 
Upchurch, D. M., Lillard, L. A., Panis, C. W. A. (2001). "The Impact of Non-Marital Childbearing on Subsequent Marital Formation and Dissolution". Chapter in Wu, Haveman, and Wolfe (Eds.), Out of Wedlock: Trends, Causes, and Consequences of Nonmarital Fertility. Russell Sage, New York.

White, L. K., and Booth, A. (1985). "The Quality and Stability of Remarriages: the role of stepchildren". American Sociological Review 50/5: 689-698. 